\title{
Transportation of maize silage to biogas plants
}

\author{
Marco Manzone, Gianfranco Airoldi, Angela Calvo \\ Department of Agricultural, Forest and Food Sciences, University of Torino, Grugliasco (TO), Italy
}

\begin{abstract}
Maize silage is one of the most used feedstock for the anaerobic digestion plants in Italy. As biomass, it is necessary to choose maize hybrids and sowing times to reach the maturity stage at the planned harvest period. In addition, the contractor has to set up transport chains considering distances and other factors affecting the forward speed in function of the supplied biogas plants.

This work examined different road conditions (length, weather and congestion) that might influence the maize silage transportation under both the energy and economic points of view. Tests were carried out with an agricultural tractor equipped with two trailers (a turntable steering and a dumper) along six itineraries $(6.2,15.3,22.1,32.5,44.4$, and $58.2 \mathrm{~km})$ in two different traffic conditions: high congestion (early morning) and low congestion (evening). Tests were also performed in two seasons with different weather conditions: late Summer and early Autumn.

The average forward speed was $27.40 \mathrm{~km} \mathrm{~h}^{-1}$ with a $15 \%$ difference between the best (evening and late Summer) and the worst (early morning and early Autumn) condition, with a productivity that varied between 9.50 and $81.98 \mathrm{~m}^{3} \mathrm{~h}^{-1}$ respectively. The performed tests confirmed that the energetic evaluation is always positive also in the longest itinerary $(58.2 \mathrm{~km})$, but the actual market value of maize silage $\left(52.00 € \mathrm{t}^{-1}\right)$ limits the convenience of the transportation distance up to $18 \mathrm{~km}$. In conclusion, the study showed that the maize silage transportation using agricultural tractors not only depends on the travelled distance, but also on the road congestion and the weather conditions.
\end{abstract}

Correspondence: Marco Manzone, Department of Agricultural, Forest and Food Sciences, University of Torino, Largo Paolo Braccini, 2, 10095 Grugliasco (TO), Italy.

E-mail: marco.manzone@unito.it

Key words: Maize silage transport; agricultural convoys; weather; road congestion; energy; cost.

Received for publication: 2 May 2019.

Accepted for publication: 5 October 2019.

${ }^{\circ}$ Copyright: the Author(s), 2020

Licensee PAGEPress, Italy

Journal of Agricultural Engineering 2020; LI:974

doi:10.4081/jae.2020.974

This article is distributed under the terms of the Creative Commons Attribution Noncommercial License (by-nc 4.0) which permits any noncommercial use, distribution, and reproduction in any medium, provided the original author(s) and source are credited.

\section{Introduction}

In these last years the importance of the biomass for energetic purposes increased, especially for its economic and energetic convenience (Spinelli et al., 2011). The biogas plants that use agricultural biomasses are very spread in all the geographic areas at small and large scales (Lijo et al., 2015). Livestock slurries, agro industry residues and cereal silages, are the main products used to feed the anaerobic digestion plants and among cereals, the maize is the most used (Negri et al., 2014). In Europe, many biogas plants are located in livestock farms. In areas with high livestock density, the land for the maize cultivation to feed AD plants can be a limiting factor. In this case, the maize silage may be available some distance away and, as a consequence, increasing the transportation costs, rising the feeding costs (Bacenetti et al., 2015).

Many Authors focused their studies on the generic biomass supply chain in different scenarios (spatial distribution of biomass, road network, ...) (Hohn et al., 2014). The main components of the transportation issues are: distance, road characteristics and traffic flow, other than biomass densities (Manzone and Calvo, 2017).

The economic, energetic and environmental sustainability may be influenced by the transportation distance (Bacenetti et al., 2016).

The choice of the vehicles may also be a critical issue (Manzone and Calvo, 2017): the biomass transportation using a truck is more flexible and cheaper for longer distances, but agricultural convoys are more suitable to load the biomass directly in field (Manzone and Balsari, 2015; Manzone and Calvo, 2017). The transport operations are nowadays studied in different agricultural crops (and forestry scenarios). Models to optimize biomass transportation were developed (Jenkins and Sutherland, 2014), but they often considered high distances, not suitable for the maize silage transportation, normally carried out within a radius of $10-50 \mathrm{~km}$. Some studies concerned the biogas production from the biomass, the anaerobic digestion management and the environmental sustainability (Dinuccio et al., 2010; Menardo et al., 2015). Few studies focused the transportation, only considering the logistic aspects and not the energy and economic sustainability. This work analysed the transportation of the maize silage using agricultural tractors and trailers that can load the product directly in field. They can also transport the biomass without intermediate unloads and loads (Manzone and Balsari, 2015), that can negatively influence the product quality and losses (Manzone, 2017). Most of biogas plant manager use contractor for maize silage harvest operated in late summer and early autumn: In about 60 days a single forage harvester runs about $600 \mathrm{~h}$ over $1800 \mathrm{ha}$ (180-210 t Wet Basis/h) filling the bunker silos of 6 1MW biogas plants. Every biogas plant has to choose hybrids and sowing times to reach the maturity stage at harvest period planned with the contractor. Contractors have to set up transport chains considering distances but also all factors affecting tractors forward speed on the path from field to plant from plant to field, determining the number of trailers required to keep harvester running. Data on bunker silos location, field distances, roads characteristic and con- 
gestion, alternative path and weather forecast are crucial to plan the proper harvesting period for each plant and in each one the daily working time necessary to reduce costs and investments. In critical traffic areas this can lead to the choice of night harvest.

The goal statement was to solve some critical issues that can come out in the transportation of the maize silage. This study examined different routes with different road conditions (as regard weather and congestion) during the maize silage transportation under both the energetic and economic points of view. The road design and congestion influence the vehicles forward speed, the working time and the fuel consumption, important parameters of the environmental impact. The transportation costs for the economic sustainability were also analysed.

Two different trailers (a turntable steering and a dumper) towed to a tractor were used in the tests. These trailers are usually present in the cereal farms and are commonly used for the biomass transportation. A unique operator was involved during all tests, avoiding the influence of different drivers' behaviour.

\section{Materials and methods}

\section{Vehicle characteristics}

Tests were carried out with a 4WD tractor (New Holland 7220) equipped with agricultural radial tires and two trailers with the same volume $\left(40 \mathrm{~m}^{3}\right)$ : a turntable steering Crosetto, CMR300, and a dumper Crosetto, NL28, both three-axle trailers and equipped with standard tires (425/65 R22.5).

A driver with three years of experience in tractor driving performed all the test.

The power of the tractor was suitable for the transport operation in different operative conditions (field, gravel and paved road), complying with the allowable forward speed in Italy (40 $\mathrm{kmh}^{-1}$ ).

\section{Itineraries considered in the tests}

Tests were carried out on six commonly used itineraries (Table 1) to transport the maize silage to the anaerobic digestion plant sited in Candiolo (Torino, Italy; GPS: E 7.55902, N 44.95578).

The six itineraries did not cross urban areas and beltways were present in all the examined cases. Since the congestion is influenced by route and weather conditions (Murat et al., 2014), all the itineraries had the same characteristics and only the length was different (Table 1).

The longest distance was $58.2 \mathrm{~km}$, because the availability of maize cultivated area for energy use can be a problem in areas with high zoo technical density. Maize was cut and chopped using a self-propelled forage harvester (John Deere 7400) and then directly loaded into the trailer in field. The biomass unload was performed tipping the trailers in the bunker silos of the biogas plant.

\section{Scenarios}

Agricultural convoys are affected by road condition and traffic volume: as a consequence they cannot travel at a constant forward speed and acceleration and deceleration rates become critical parameters influencing fuel consumption and working time.

The tested convoys travelled each itinerary in two different day times, with different traffic volumes: early morning (high congestion) and evening (low congestion). Tests were also performed in two different road conditions: wet and dry. In the Southern Europe, wet roads are normally present during the Autumn (when fog and moisture are present). During the Summer roads are usually dry, because temperatures are higher (until $35^{\circ} \mathrm{C}$ ) and rain events are occasional. The tests were carried out in 2017 , in the second half of August (late Summer) and in the second half of October (early Autumn).

Three repetitions were performed for each roundtrip (144 tests): in the forward journey the trailer was laden, in the return it was unladen.

\section{Travel time consumption and productivity}

The productive travel time was acquired following the procedure set up by Magagnotti and Spinelli (2012). The net-working time (NWT; normal travel condition: roundabouts, traffic lights, intersections), the complementary working times (CWT; trailers laden and unladen) and the unproductive working times (UWT; delays referred to unpredictable events during the transportation: roadworks and road accidents) were acquired .

In this study waiting times related to the load of the chopped maize in field and to the unload of the biomass in the biogas plant were not considered because they are influenced by the logistic aspects and not by the transport conditions. A digital stopwatch with a centesimal readability (Hanhart ${ }^{\circledR}$ Profile 5) was used to acquire NWts, CWTs and UWTs.

The average travel speed was calculated dividing the travel distance by the travel time. The productivity was in $\mathrm{m}^{3} \mathrm{~h}^{-1}$ and in $\mathrm{m}^{3} \mathrm{~km}^{-1}$.

\section{Energy evaluation}

\section{Energy output}

In this study, the output of the transport operation was the energy content of the transported biomass. This value was calculated as a function of the biomass density, dry matter content and high heating value. The transported maize silage had an average density of

Table 1. Route characteristics.

\begin{tabular}{|c|c|c|c|c|c|c|c|c|}
\hline Itinerary & From & To & $\begin{array}{l}\text { Lenght } \\
\text { (km) }\end{array}$ & $\begin{array}{l}\text { Roundabout } \\
\text { (n) }\end{array}$ & $\begin{array}{l}\text { Intersection } \\
\text { (n) }\end{array}$ & $\begin{array}{l}\text { Traffic light } \\
\text { (n) }\end{array}$ & $\begin{array}{l}\text { Railway crossing } \\
\text { (n) }\end{array}$ & $\begin{array}{l}\text { Gravel road } \\
\text { (m) }\end{array}$ \\
\hline A & None & Candiolo & 6.2 & 3 & 4 & 1 & 1 & 390 \\
\hline B & Virle & Candiolo & 15.3 & 5 & 5 & 2 & 0 & 488 \\
\hline $\mathrm{C}$ & Vigone & Candiolo & 22.1 & 8 & 6 & 1 & 0 & 680 \\
\hline D & Villafranca & Candiolo & 32.5 & 7 & 9 & 3 & 0 & 634 \\
\hline $\mathrm{E}$ & Marene & Candiolo & 44.4 & 11 & 9 & 2 & 0 & 340 \\
\hline $\mathrm{F}$ & Fossano & Candiolo & 58.2 & 15 & 10 & 4 & 0 & 510 \\
\hline
\end{tabular}


$320 \mathrm{kgm}^{-3}$ (measured during the load operation). The density of the biomass was calculated weighting each trailer by a certified weighbridge (GOMBA ${ }^{\circledR}$ T5, $20 \mathrm{~kg}$ of readability): the loaded biomass was previously levelled in the trailer body.

The average moisture content was $67 \%$. It was calculated using three samples ( $1 \mathrm{~kg}$ each), randomly selected from each trailer before unloading. The gravimetric method was used for the moisture evaluation, by a ventilated stove with an internal temperature of $103^{\circ} \mathrm{C}$ (UNI EN 14774-2, 2010). A precision digital scale (METTLER TOLEDO ${ }^{\circledR}$ MS12002TS) was used, with an accuracy of $0.01 \mathrm{~kg}$ for each measurement.

The three samples were useful also to calculate the maize silage energy content, measuring the dry matter and the high heating value (HHV), as indicated for biomass for energy use (Magagnotti and Spinelli, 2012). The HHV was determined by the European Standard UNI EN 14918 (2010), using an oxygen bomb calorimeter (IKA $\left.{ }^{\circledR} \mathrm{C} 200\right)$. The low heating value (LHV) was calculated using Equation 1 (Magagnotti and Spinelli, 2012).

$L H V=(S d w \cdot H H V)-(W w \cdot E w)$

where:

$L H V=$ low heating value $(\mathrm{MJ})$;

$S d w=$ dry maize silage mass $(\mathrm{kg})$;

$H H V=$ high heating value $\left(\mathrm{MJ} \mathrm{kg}^{-1}\right)$;

$W w=$ water weight $(\mathrm{kg})$;

$E w=$ amount of energy needed to evaporate the water in the biomass $\left(2.5 \mathrm{MJ} \mathrm{kg}^{-1}\right)$.

\section{Energy input}

The energy consumption related to the biomass transportation was determined considering the direct energy content (fuel and lubricant consumption) and the indirect energy spent for machines manufacturing.

The input and output energy values of the biomass transportation were calculated multiplying fuel and lubricant consumption (and the amount of other different inputs) by specific energy coefficients. The energy content was $37.0 \mathrm{MJ} \mathrm{L}^{-1}$ for fuel and $83.7 \mathrm{MJ}$ $\mathrm{kg}^{-1}$ for lubricant. An additional energy value inflation of $1.2 \mathrm{MJ}$ $\mathrm{kg}^{-1}$ (linked to the product transportation) was assumed for fuel and lubricant. Equation 2 was used to calculate the energy consumption $\left(\mathrm{E}_{\mathrm{C}}\right)$ related to the machine use:

$$
E_{C}=\frac{E_{M} \cdot E_{L} \cdot M}{W_{T} \cdot U_{P}}
$$

where:

$\mathrm{E}_{\mathrm{C}}=$ energy consumption related to the machine use $\left(\mathrm{MJ} \mathrm{m}^{-3}\right)$;

$\mathrm{E}_{\mathrm{M}}=$ energy embedded in the machine $\left(\mathrm{MJ} \mathrm{kg}^{-1}\right.$ per year);

$\mathrm{E}_{\mathrm{L}}=$ economic life of the machine (years);

$\mathrm{M}=$ mass of the machine $(\mathrm{kg})$;

$\mathrm{W}_{\mathrm{T}}=$ annual working time $(\mathrm{h})$;

$\mathrm{UP}_{\mathrm{P}}=$ unit of production $\left(\mathrm{m}^{3} \mathrm{~h}^{-1}\right)$.

Different energy coefficients were considered in function of the machine type: $9.5 \mathrm{MJ} \mathrm{kg}^{-1}$ per year for the tractor and $7.0 \mathrm{MJ}$ $\mathrm{kg}^{-1}$ per year for the trailers. Tractor was assumed to have an useful life of $10,000 \mathrm{~h}$, while $3000 \mathrm{~h}$ were considered for the trailer. The surveyed annual utilization was 580 hours for the tractor (used also for other agricultural activities) and 190 hours for the trailer. Repair and maintenance used the 55\% of the energy content for machine manufacturing (Fluck, 1985) and it was part of the indi- rect energy. Fuel consumed during the biomass transportation was measured by the topping-off system (tank refilling at the end of the travel). The tank was refilled with a measurement accuracy of 0.02 liters (Manzone and Spinelli, 2014). The consumed lubricant was estimated as $2 \%$ of fuel consumption (ASAE, 1999).

\section{Energy parameters}

The energy balance (EB) was the method to evaluate the energy efficiency of the transport operation for agricultural systems. It was calculated as the ratio between energy output $\left(\mathrm{MJ} \mathrm{m}^{-3}\right)$ and energy input $\left(\mathrm{MJ} \mathrm{m}^{-3}\right)$ [Eq. (3)]. Other energy indices related to transportation were: the energy productivity (EP), the specific energy (SE) and the net energy (NE) [Eqs. (4-6)]. The energy productivity was calculated both per volume $\left(\mathrm{EP}_{\mathrm{V}}\right)(4 \mathrm{a})$ and per distance unit $\left(\mathrm{EP}_{\mathrm{d}}\right)(4 \mathrm{~b})$.

$$
E B=\frac{E o m}{E i m}
$$

where:

EB: energy balance;

Eom: energy output $\left[\mathrm{MJ} \mathrm{m}^{-3}\right]$;

Eim: energy input $\left[\mathrm{MJ} \mathrm{m}^{-3}\right]$;

$$
E P_{v}=\frac{S o}{E i h}
$$

where:

$\mathrm{EP}_{\mathrm{v}}$ : energy productivity per volume unit $\left[\mathrm{m}^{3} \mathrm{MJ}^{-1}\right]$;

So: maize silage output $\left[m^{3} h^{-1}\right]$;

Eih: energy input $\left[\mathrm{MJ}^{-1}\right]$.

$$
E P_{d}=\frac{F s}{E i h}
$$

where:

$\mathrm{EP}_{\mathrm{d}}$ : energy productivity per distance unit $\left[\mathrm{kmMJ}^{-1}\right]$; Fs: forward speed $\left[\mathrm{km} \mathrm{h}^{-1}\right]$;

Eih: energy input $\left[M J^{-1}\right]$.

$$
S E=\frac{E i h}{S o}
$$

where:

SE: specific energy $\left[\mathrm{MJm}^{-3}\right]$;

Eih: energy input $\left[M J h^{-1}\right]$;

So: biomass output $\left[m^{3} h^{-1}\right]$.

$N E=E o m-E i m$

where:

$\mathrm{NE}$ : net energy $\left[\mathrm{MJm}^{-3}\right]$;

EOm: energy output $\left[\mathrm{MJ} \mathrm{m}^{-3}\right]$;

Eim: energy input $\left[\mathrm{MJ} \mathrm{m}^{-3}\right]$.

The manpower was calculated only per time unit and it was not considered in the energy evaluation. 


\section{Hourly costs}

Transportation costs were calculated considering tractor and trailer hourly costs. The machine fixed costs were determined using the procedures as in Sopegno et al. (2016). The economic evaluation considered the useful life and annual utilizations of the machines as in the energy evaluation. The purchase cost of the tractor and the trailers was respectively $85,500.00 €$ and $25,000.00$ $€$. Repair and maintenance costs were directly obtained by the vehicles owner updated to the current year (2019). The cost of the tractor driver was $18.50 € \mathrm{~h}^{-1}$ (including insurance and health costs). The fuel and lubricant costs were $0.90 € \mathrm{~kg}^{-1}$ and $5.50 € \mathrm{~kg}^{-1}$. In the Northwest Italy, during the study development, the average market price of the maize silage was about $52.00 € \mathrm{t}^{-1}$, wet basis $\left(80.00 € \mathrm{tDM}^{-1}\right)$. Considering the fixed costs (harvesting and in field crop purchase) and a $20 \%$ of profit, it is possible to assume a maximum cost of $4.70 € \mathrm{t}^{-1}\left(1.47 € \mathrm{~m}^{-3}\right)$ for the biomass transportation. The economic sustainability of the transport operation was determined adopting the net present value (NPV), the difference between the total income and the total costs.

\section{Statistical analysis}

Data were processed using IBM-SPSS Advanced Statistic Package, version 24. The ANOVA test was used, with a significance level equal to 0.05 . The ANOVA procedures were executed after testing the variance homogeneity. The Tukey's post-hoc analysis was the method to compare individual means.

\section{Results}

\section{Differences between the two tractor-trailers combina- tions}

The statistical analysis highlighted any significant difference between the two tractor-trailer combinations in all different conditions, both in transportation times and fuel consumption (Table 2).

The two tractor-trailer combinations (the same tractor towing different trailers, gained energetic and economic results not statistically different.

Statistics did not show any difference between the two combinations also in the manoeuvre times because the different structure of the trailers was negligible in our test conditions due to the large dimension of both the field heads and the bunker silos. For these reasons, all the further elaborations were carried out without considering the factor tractor-trailer combination.

\section{Transportation times and productivity}

The travel time (variable between 0.49 and $4.21 \mathrm{~h}$ ) was influenced by the itinerary length (Table 3 ), congestion and, only in particular situations, by the weather conditions (Figure 1). The itineraries $\mathrm{C}$ and $\mathrm{F}$ registered higher travel times in late harvest season when a long-lasting fog was present along the route.

The unproductive working times (UWT) were always under the $1 \%$ of the total travel time. The average loading time in field was around $11 \mathrm{~min}$, while the unloading time in biogas plant bunker silo was about 4 min - including, in both cases, times for manoeuvres. Loading and unloading times (CWT) less influenced the net transportation times (NWT) closely related to the length of the route (Figure 2): in any case the return travel (unladen) has always been characterized by a shorter travel time. The NWT per kilometre ranged between 4 and 5.9 minutes respectively for longer and shorter itineraries.

The average forward speed (and consequently the NWT) was affected by the different traffic conditions (Table 3 ) and it increased from 3-4 $\mathrm{kmh}^{-1}$ during the evening to $8 \mathrm{kmh}^{-1}$ in the shortest itinerary (Figure 3).

The productivity varied between 9.50 and $81.98 \mathrm{~m}^{3} \mathrm{~h}^{-1}$; the highest value was observed with lower congestion, at the beginning of the harvest season in late summer and in the shorter itineraries.

The manpower was in the range of 44.14 and 379.22 second $\mathrm{m}^{-3} \mathrm{~km}^{-1}$ per work unit (UW) (Table 3).

Statistical analysis highlighted a higher variability among the data along the different itineraries, with the exception of travel speed in itineraries B and C as well as in itineraries E and F (Table 4).
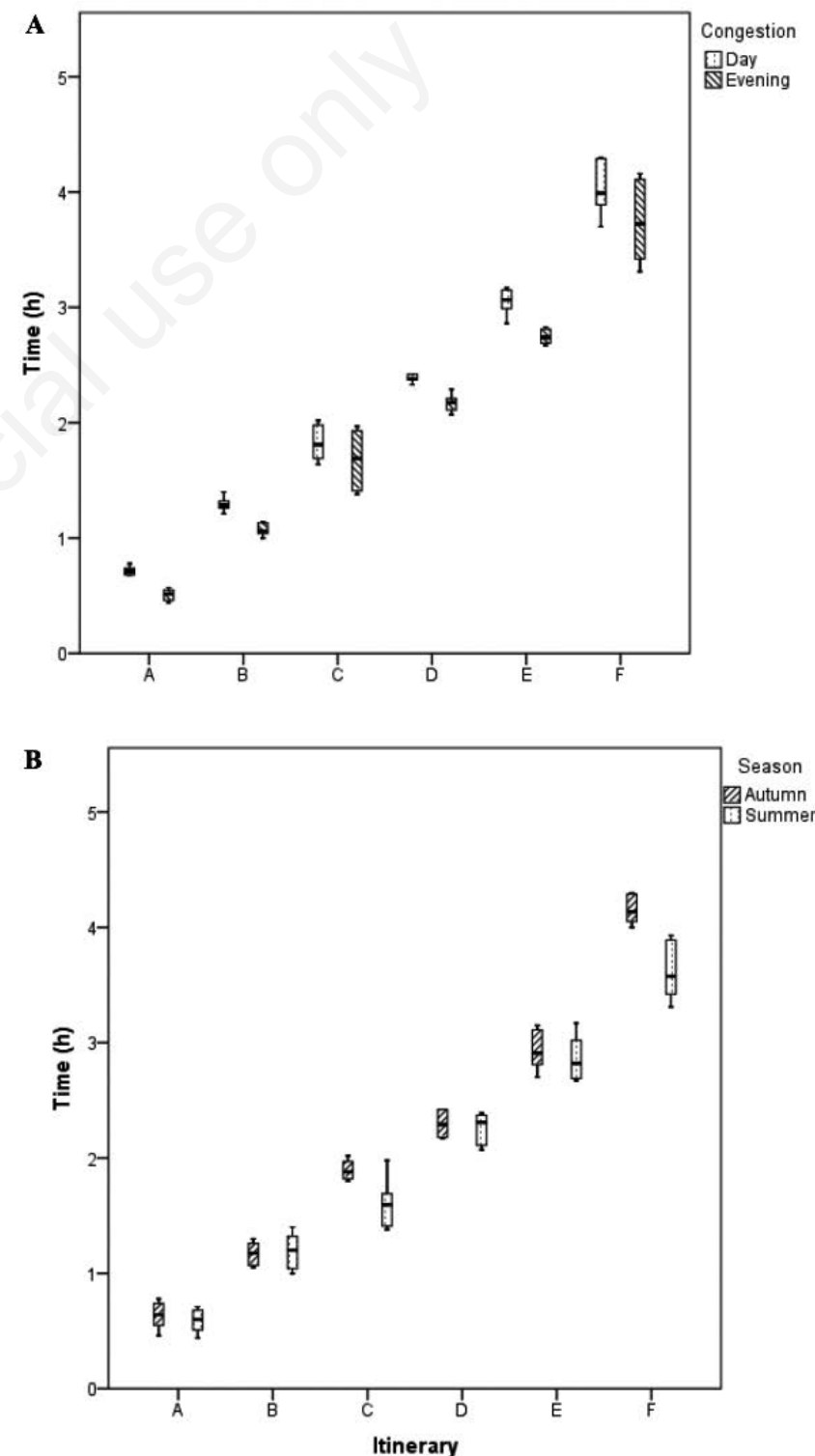

Figure 1. Transportation times along the six itineraries and with different congestion (A) and weather (B) conditions. 


\section{Energy consumption}

The average HHV of the transported maize silage was $18.6 \pm$ $0.47 \mathrm{MJ} \cdot \mathrm{kg}^{-1}$, while the LHV was $4.6 \pm 0.21 \mathrm{MJ} \cdot \mathrm{kg}^{-1}$. These values are in line with other studies carried out in other geographical areas (Pordesimo et al., 2005).
The total energy required varied from 5.99 to $74.52 \mathrm{MJ} \mathrm{m}^{-3}$ in function of the itinerary length (Table 5).

The main component of the total energy was the direct energy, that varied exponentially in function of the travelled distance, unlike the linear variation of the indirect energy (Figure 4). In these figures the curve which best fits the direct and indirect aver-

Table 2. GLM output of the transportation times (time) and fuel consumption (consumption) obtained by the two combinations tractor-trailer in the different test conditions (itinerary, season and congestion).

\begin{tabular}{|c|c|c|c|c|c|c|}
\hline Origin & & ss & df & Ms & $\mathbf{F}$ & P-value \\
\hline Corrected model & $\begin{array}{l}\text { Time } \\
\text { Consumption }\end{array}$ & $\begin{array}{c}169.565^{\mathrm{a}} \\
6167.792^{\mathrm{b}}\end{array}$ & $\begin{array}{l}4 \\
4\end{array}$ & $\begin{array}{c}42.391 \\
1541.948\end{array}$ & $\begin{array}{l}1221.128 \\
1221.872\end{array}$ & $\begin{array}{l}<0.0001 \\
<0.0001\end{array}$ \\
\hline Intercept & $\begin{array}{l}\text { Time } \\
\text { Consumption }\end{array}$ & $\begin{array}{l}0.090 \\
3.224\end{array}$ & $\begin{array}{l}1 \\
1\end{array}$ & $\begin{array}{l}0.090 \\
3.224\end{array}$ & $\begin{array}{l}2.591 \\
2.555\end{array}$ & $\begin{array}{l}0.110 \\
0.112\end{array}$ \\
\hline Itinerary & $\begin{array}{l}\text { Time } \\
\text { Consumption }\end{array}$ & $\begin{array}{c}166.673 \\
6065.978\end{array}$ & $\begin{array}{l}1 \\
1\end{array}$ & $\begin{array}{c}166.673 \\
6065.978\end{array}$ & $\begin{array}{l}4801.192 \\
4806.807\end{array}$ & $\begin{array}{l}<0.0001 \\
<0.0001\end{array}$ \\
\hline Season & $\begin{array}{l}\text { Time } \\
\text { Consumption }\end{array}$ & $\begin{array}{c}0.893 \\
32.348\end{array}$ & $\begin{array}{l}1 \\
1 \\
\end{array}$ & $\begin{array}{c}0.893 \\
32.348\end{array}$ & $\begin{array}{l}25.725 \\
25.633 \\
\end{array}$ & $\begin{array}{l}<0.0001 \\
<0.0001\end{array}$ \\
\hline Congestion & $\begin{array}{l}\text { Time } \\
\text { Consumption }\end{array}$ & $\begin{array}{c}1.904 \\
69.375\end{array}$ & $\begin{array}{l}1 \\
1\end{array}$ & $\begin{array}{r}1.904 \\
69.375\end{array}$ & $\begin{array}{l}54.858 \\
54.974\end{array}$ & $\begin{array}{l}<0.0001 \\
<0.0001\end{array}$ \\
\hline Trailer & $\begin{array}{l}\text { Time } \\
\text { Consumption }\end{array}$ & $\begin{array}{l}0.095 \\
0.092\end{array}$ & $\begin{array}{l}1 \\
1 \\
\end{array}$ & $\begin{array}{l}0.095 \\
0.092\end{array}$ & $\begin{array}{l}2.739 \\
0.073\end{array}$ & $\begin{array}{l}0.100 \\
0.788\end{array}$ \\
\hline Error & $\begin{array}{l}\text { Time } \\
\text { Consumption }\end{array}$ & $\begin{array}{c}4.825 \\
175.412\end{array}$ & $\begin{array}{l}139 \\
139\end{array}$ & $\begin{array}{l}0.035 \\
1.262\end{array}$ & & \\
\hline Total & $\begin{array}{l}\text { Time } \\
\text { Consumption }\end{array}$ & $\begin{array}{c}810.355 \\
29494.602\end{array}$ & $\begin{array}{l}144 \\
144 \\
\end{array}$ & & & \\
\hline Corrrected total & $\begin{array}{l}\text { Time } \\
\text { Consumption }\end{array}$ & $\begin{array}{c}174.391 \\
6343.204 \\
\end{array}$ & $\begin{array}{l}143 \\
143 \\
\end{array}$ & & & \\
\hline
\end{tabular}

${ }^{a}$ R-squared $=.972$ (R-squared corrected $\left.=.972\right)$. bR-squared = .972 (R-squared corrected = .972). ss, sum of squares; df, degree of freedom; Ms, mean square; F, F test; P-value, significance.

Table 3. Descriptive statistic of the travelled time (Time), forward speed (Speed), productivity and manpower parameters.

\begin{tabular}{|c|c|c|c|c|c|c|c|c|c|c|}
\hline \multirow[t]{2}{*}{ Itinerary } & \multirow[t]{2}{*}{ Season } & \multirow[t]{2}{*}{ Congestion } & \multicolumn{2}{|c|}{$\begin{array}{l}\text { Time } \\
\text { (s) }\end{array}$} & \multicolumn{2}{|c|}{$\begin{array}{c}\text { Speed } \\
\left(\mathrm{kmh}^{-1}\right)\end{array}$} & \multicolumn{2}{|c|}{$\begin{array}{c}\text { Productivity } \\
\left(\mathrm{m}^{3} \mathrm{~h}^{-1}\right)\end{array}$} & \multicolumn{2}{|c|}{$\begin{array}{l}\text { Manpower } \\
\left(\mathrm{sm}^{-3} \mathrm{~km}^{-1}\right)\end{array}$} \\
\hline & & & Mean & SD & Mean & SD & Mean & SD & Mean & SD \\
\hline A & $\begin{array}{l}\text { Summer } \\
\text { Autumn }\end{array}$ & $\begin{array}{l}\text { Day } \\
\text { Evening } \\
\text { Day } \\
\text { Evening }\end{array}$ & $\begin{array}{l}0.69 \\
0.49 \\
0.74 \\
0.53\end{array}$ & $\begin{array}{l}0.02 \\
0.04 \\
0.04 \\
0.06\end{array}$ & $\begin{array}{l}18.49 \\
26.21 \\
17.31 \\
24.58\end{array}$ & $\begin{array}{l}0.51 \\
2.34 \\
0.83 \\
2.72\end{array}$ & $\begin{array}{l}57.82 \\
81.98 \\
54.14 \\
76.86\end{array}$ & $\begin{array}{l}1.58 \\
7.32 \\
2.58 \\
8.49\end{array}$ & $\begin{array}{l}62.29 \\
44.14 \\
66.59 \\
47.20\end{array}$ & $\begin{array}{l}1.73 \\
3.78 \\
3.17 \\
4.95\end{array}$ \\
\hline B & $\begin{array}{l}\text { Summer } \\
\text { Autumn }\end{array}$ & $\begin{array}{l}\text { Day } \\
\text { Evening } \\
\text { Day } \\
\text { Evening }\end{array}$ & $\begin{array}{l}1.33 \\
1.06 \\
1.26 \\
1.09\end{array}$ & $\begin{array}{l}0.07 \\
0.07 \\
0.05 \\
0.05\end{array}$ & $\begin{array}{l}23.40 \\
29.53 \\
24.78 \\
28.66\end{array}$ & $\begin{array}{l}1.14 \\
1.85 \\
0.87 \\
1.15\end{array}$ & $\begin{array}{l}30.10 \\
38.00 \\
31.89 \\
36.87\end{array}$ & $\begin{array}{l}1.46 \\
2.38 \\
1.11 \\
1.48\end{array}$ & $\begin{array}{c}119.77 \\
94.98 \\
112.99 \\
97.73\end{array}$ & $\begin{array}{l}5.90 \\
6.05 \\
3.91 \\
3.99\end{array}$ \\
\hline $\mathrm{C}$ & $\begin{array}{l}\text { Summer } \\
\text { Autumn }\end{array}$ & $\begin{array}{l}\text { Day } \\
\text { Evening } \\
\text { Day } \\
\text { Evening }\end{array}$ & $\begin{array}{l}1.77 \\
1.45 \\
1.88 \\
1.91 \\
\end{array}$ & $\begin{array}{l}0.18 \\
0.09 \\
0.12 \\
0.07\end{array}$ & $\begin{array}{l}25.52 \\
31.16 \\
23.92 \\
23.50\end{array}$ & $\begin{array}{l}2.49 \\
1.98 \\
1.50 \\
0.89\end{array}$ & $\begin{array}{l}22.74 \\
27.76 \\
21.31 \\
20.94\end{array}$ & $\begin{array}{l}2.22 \\
1.76 \\
1.34 \\
0.79\end{array}$ & $\begin{array}{l}159.37 \\
130.01 \\
169.36 \\
172.09\end{array}$ & $\begin{array}{c}16.42 \\
8.52 \\
11.03 \\
6.43\end{array}$ \\
\hline D & $\begin{array}{l}\text { Summer } \\
\text { Autumn }\end{array}$ & $\begin{array}{l}\text { Day } \\
\text { Evening } \\
\text { Day } \\
\text { Evening }\end{array}$ & $\begin{array}{l}2.36 \\
2.16 \\
2.40 \\
2.19\end{array}$ & $\begin{array}{l}0.03 \\
0.12 \\
0.03 \\
0.02\end{array}$ & $\begin{array}{l}27.74 \\
30.53 \\
27.32 \\
29.97\end{array}$ & $\begin{array}{l}0.35 \\
1.63 \\
0.33 \\
0.25\end{array}$ & $\begin{array}{l}16.91 \\
18.60 \\
16.65 \\
18.27\end{array}$ & $\begin{array}{l}0.21 \\
1.00 \\
0.20 \\
0.15\end{array}$ & $\begin{array}{l}212.94 \\
193.87 \\
216.26 \\
197.06\end{array}$ & $\begin{array}{c}2.64 \\
10.65 \\
2.60 \\
1.67\end{array}$ \\
\hline $\mathrm{E}$ & $\begin{array}{l}\text { Summer } \\
\text { Autumn }\end{array}$ & $\begin{array}{l}\text { Day } \\
\text { Evening } \\
\text { Day } \\
\text { Evening }\end{array}$ & $\begin{array}{l}3.02 \\
2.71 \\
3.08 \\
2.78\end{array}$ & $\begin{array}{l}0.16 \\
0.06 \\
0.08 \\
0.07\end{array}$ & $\begin{array}{l}29.46 \\
32.71 \\
28.80 \\
31.93\end{array}$ & $\begin{array}{l}1.55 \\
0.68 \\
0.77 \\
0.79\end{array}$ & $\begin{array}{l}13.28 \\
14.74 \\
12.98 \\
14.39\end{array}$ & $\begin{array}{l}0.70 \\
0.30 \\
0.35 \\
0.36\end{array}$ & $\begin{array}{l}271.60 \\
244.22 \\
277.50 \\
250.21\end{array}$ & $\begin{array}{c}14.22 \\
5.10 \\
7.31 \\
6.12\end{array}$ \\
\hline $\mathrm{F}$ & $\begin{array}{l}\text { Summer } \\
\text { Autumn }\end{array}$ & $\begin{array}{l}\text { Day } \\
\text { Evening } \\
\text { Day } \\
\text { Evening }\end{array}$ & $\begin{array}{l}3.84 \\
3.39 \\
4.21 \\
4.09\end{array}$ & $\begin{array}{l}0.12 \\
0.07 \\
0.14 \\
0.08\end{array}$ & $\begin{array}{l}30.81 \\
34.86 \\
28.10 \\
28.93\end{array}$ & $\begin{array}{l}1.02 \\
0.80 \\
0.96 \\
0.60\end{array}$ & $\begin{array}{c}10.42 \\
11.78 \\
9.50 \\
9.78\end{array}$ & $\begin{array}{l}0.34 \\
0.27 \\
0.32 \\
0.21\end{array}$ & $\begin{array}{l}345.86 \\
305.56 \\
379.22 \\
368.12\end{array}$ & $\begin{array}{c}11.26 \\
6.97 \\
12.64 \\
7.61\end{array}$ \\
\hline
\end{tabular}

The values in the table are the mean of the three replications. SD, standard deviation. 
age values is represented with dot lines, while the curves that represent the minimum and the maximum values are continuous lines. The minimum values refer to the best travel conditions (during the evening at the beginning of harvest season in late Summer): the maximum values resulted in daytime travels in the late harvest season (early Autumn).

The direct energy consumption was function of both itinerary length and road conditions, and values varied between $10 \%$ in itinerary D and $120 \%$ in itinerary E. The indirect energy data had a variation between $12 \%$ in itinerary $\mathrm{D}$ and $47 \%$ in itinerary $\mathrm{A}$.
The statistical analysis - performed on the direct, indirect and maintenance energy consumption per meter cube of transported biomass - evidenced differences among all the itineraries; likeness were obtained in the two periods of the harvest season and in the different traffic conditions (Table 4).

\section{Energy balance, specific energy, energy productivity and net energy}

Energy balance, energy productivity and net energy were

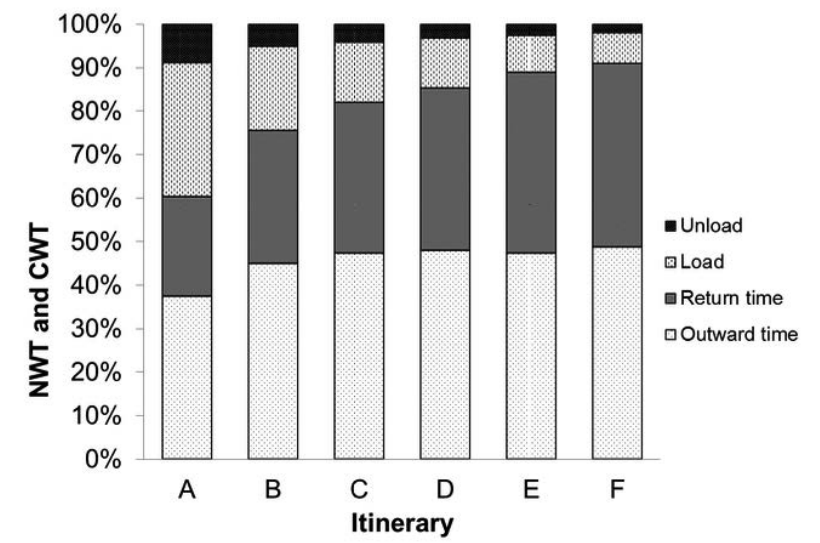

Figure 2. Net-working times (NWT) and complementary working times (CWT) contributions in the different itineraries.

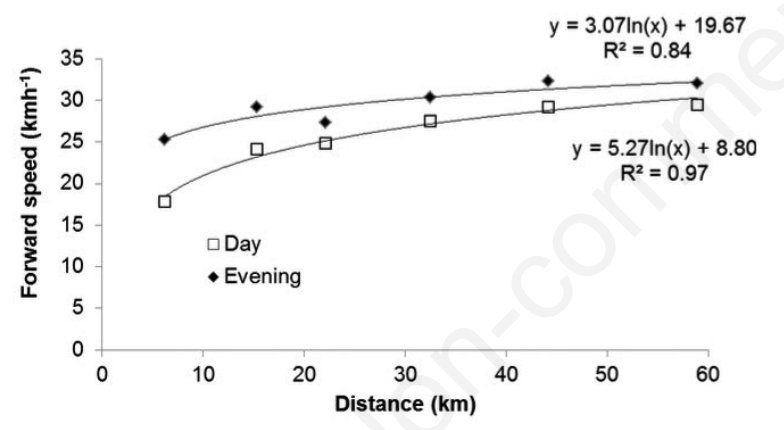

Figure 3. Averaged travel times in different congestion scenarios versus the travelled distance $\left(P<0.0001\right.$ in both the curves). $R^{2}=$ $\mathrm{R}$ squared statistic.
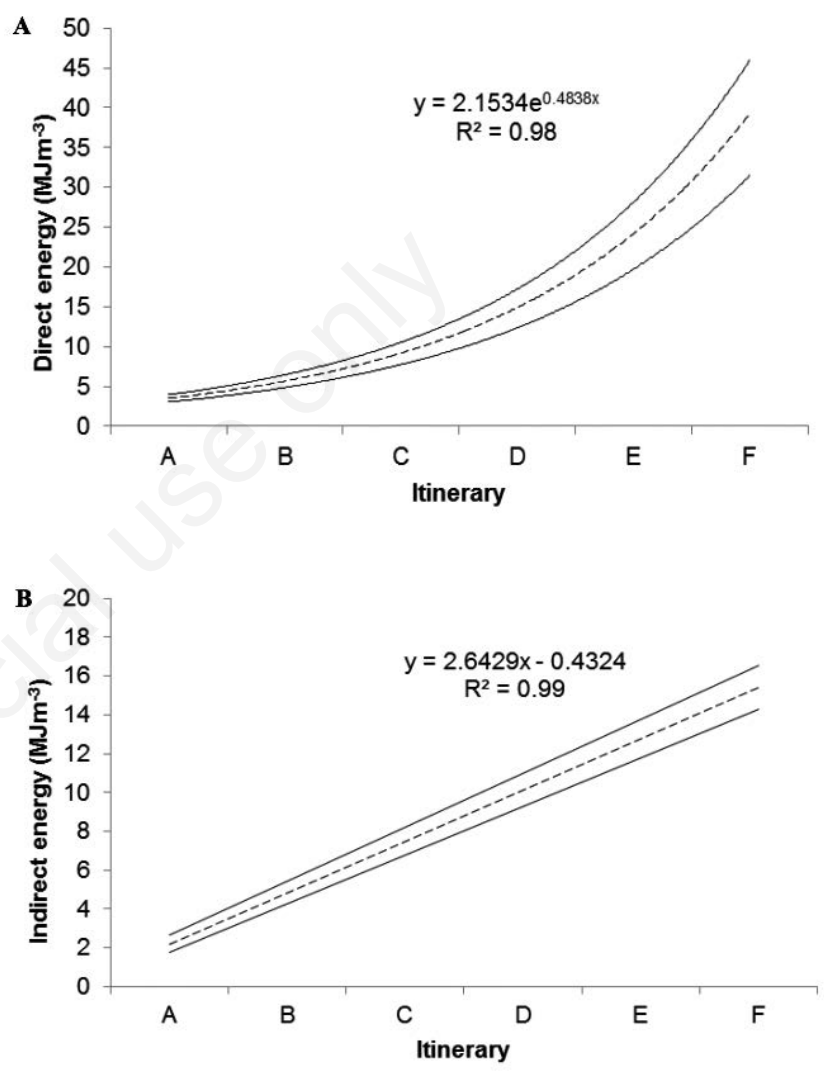

Figure 4. A) Direct energy consumption $\left(\mathrm{MJ} \mathrm{m}^{-3}\right)$ and (B) indirect energy consumption $\left(\mathrm{MJm}^{-3}\right)$ in function of the travelled distance (average: dot line, minimum and maximum continuous lines) $(\mathbf{P}<\mathbf{0 . 0 0 0 1}) . \mathbf{R}^{2}=\mathbf{R}$ squared statistic.

Table 4. ANOVA table.

\begin{tabular}{|c|c|c|c|c|c|c|c|c|c|c|c|}
\hline & & $\begin{array}{l}\text { Time } \\
\text { (h) }\end{array}$ & $\begin{array}{c}\text { Speed } \\
\left(\mathrm{kmh}^{-1}\right)\end{array}$ & $\begin{array}{l}\text { Product. } \\
\left(m^{3} h^{-1}\right)\end{array}$ & $\begin{array}{c}\text { Direct } \\
\text { energy } \\
\left(\mathrm{MJm}^{-3}\right)\end{array}$ & $\begin{array}{c}\text { Mainten. } \\
\text { energy } \\
\left(\mathrm{MJm}^{-3}\right)\end{array}$ & $\begin{array}{c}\text { Indirect } \\
\text { energy } \\
\left(\mathrm{MJm}^{-3}\right)\end{array}$ & $\begin{array}{l}\text { Energy } \\
\text { balance }\end{array}$ & $\begin{array}{c}\text { Specific } \\
\text { energy } \\
\left(\mathrm{MJm}^{-3}\right)\end{array}$ & $\begin{array}{l}\text { Net energy } \\
\left(\mathrm{MJm}^{-3}\right)\end{array}$ & $\begin{array}{l}\text { Energy } \\
\text { product. } \\
\left(\mathrm{m}^{3} \mathrm{MJ}^{-1}\right)\end{array}$ \\
\hline Itinerary & $\begin{array}{l}\text { A } \\
\text { B } \\
\text { C } \\
\text { D } \\
\text { E } \\
\text { F }\end{array}$ & $\begin{array}{l}0.61^{\mathrm{a}} \\
1.18^{\mathrm{b}} \\
1.75^{\mathrm{c}} \\
2.28^{\mathrm{d}} \\
2.90^{\mathrm{e}} \\
3.88^{\mathrm{f}}\end{array}$ & $\begin{array}{l}21.65^{\mathrm{a}} \\
26.59^{\mathrm{b}} \\
26.02^{\mathrm{b}} \\
28.89^{\mathrm{c}} \\
30.73^{\mathrm{d}} \\
30.68^{\mathrm{d}}\end{array}$ & $\begin{array}{l}67.70^{\mathrm{a}} \\
34.22^{\mathrm{b}} \\
23.19^{\mathrm{c}} \\
17.61^{\mathrm{d}} \\
13.85^{\mathrm{e}} \\
10.37^{\mathrm{f}}\end{array}$ & $\begin{array}{c}3.43^{\mathrm{a}} \\
6.38^{\mathrm{b}} \\
9.34^{\mathrm{c}} \\
12.07^{\mathrm{d}} \\
24.03^{\mathrm{e}} \\
43.48^{\mathrm{f}}\end{array}$ & $\begin{array}{l}1.41^{\mathrm{a}} \\
2.73^{\mathrm{b}} \\
4.04^{\mathrm{c}} \\
5.26^{\mathrm{d}} \\
6.69^{\mathrm{e}} \\
8.97^{\mathrm{f}}\end{array}$ & $\begin{array}{c}2.57^{\mathrm{a}} \\
4.96^{\mathrm{b}} \\
7.35^{\mathrm{c}} \\
9.56^{\mathrm{d}} \\
12.16^{\mathrm{e}} \\
16.30^{\mathrm{f}}\end{array}$ & $\begin{array}{c}471.83^{\mathrm{a}} \\
243.02^{\mathrm{b}} \\
165.68^{\mathrm{c}} \\
126.20^{\mathrm{d}} \\
99.47^{\mathrm{e}} \\
74.63^{\mathrm{f}}\end{array}$ & $\begin{array}{l}6.26^{\mathrm{a}} \\
11.85^{\mathrm{b}} \\
17.45^{\mathrm{c}} \\
22.61^{\mathrm{d}} \\
28.69^{\mathrm{e}} \\
38.38^{\mathrm{f}}\end{array}$ & $\begin{array}{l}3376.59^{\mathrm{a}} \\
3369.93^{\mathrm{b}} \\
3363.26^{\mathrm{c}} \\
3357.11^{\mathrm{d}} \\
3349.86^{\mathrm{e}} \\
3338.32^{\mathrm{f}}\end{array}$ & $\begin{array}{l}0.165^{\mathrm{a}} \\
0.085^{\mathrm{b}} \\
0.058^{\mathrm{c}} \\
0.044^{\mathrm{d}} \\
0.035^{\mathrm{e}} \\
0.026^{\mathrm{f}}\end{array}$ \\
\hline Seas. & $\begin{array}{l}\text { Sum. } \\
\text { Aut. }\end{array}$ & $\begin{array}{l}2.02^{\mathrm{a}} \\
2.18^{\mathrm{a}}\end{array}$ & $\begin{array}{l}28.37^{\mathrm{a}} \\
26.48^{\mathrm{b}}\end{array}$ & $\begin{array}{l}28.68^{\mathrm{a}} \\
26.97^{\mathrm{b}}\end{array}$ & $\begin{array}{l}10.75^{a} \\
11.56 a\end{array}$ & $\begin{array}{l}4.67^{\mathrm{a}} \\
5.03^{\mathrm{a}}\end{array}$ & $\begin{array}{l}8.49^{\mathrm{a}} \\
9.15^{\mathrm{a}}\end{array}$ & $\begin{array}{l}202.74^{\mathrm{a}} \\
190.87^{\mathrm{a}}\end{array}$ & $\begin{array}{l}20.10^{\mathrm{a}} \\
21.64^{\mathrm{a}}\end{array}$ & $\begin{array}{l}3360.10^{\mathrm{a}} \\
3358.26^{\mathrm{a}}\end{array}$ & $\begin{array}{l}0.058^{\mathrm{a}} \\
0.054^{\mathrm{a}}\end{array}$ \\
\hline Cong. & $\begin{array}{c}\text { Day } \\
\text { Even. }\end{array}$ & $\begin{array}{l}2.22^{\mathrm{a}} \\
1.99^{\mathrm{a}}\end{array}$ & $\begin{array}{l}25.47^{\mathrm{a}} \\
29.38^{\mathrm{b}}\end{array}$ & $\begin{array}{l}24.81^{\mathrm{a}} \\
30.83^{\mathrm{b}}\end{array}$ & $\begin{array}{l}11.75^{\mathrm{a}} \\
10.56^{\mathrm{a}}\end{array}$ & $\begin{array}{l}5.12^{\mathrm{a}} \\
4.58^{\mathrm{a}}\end{array}$ & $\begin{array}{l}9.30^{\mathrm{a}} \\
8.33^{\mathrm{a}}\end{array}$ & $\begin{array}{l}176.24^{\mathrm{a}} \\
217.37^{\mathrm{b}}\end{array}$ & $\begin{array}{c}22.00^{\mathrm{a}} \\
19.74 \mathrm{~b}^{\mathrm{b}}\end{array}$ & $\begin{array}{l}3357.83^{\mathrm{a}} \\
3360.52^{\mathrm{a}}\end{array}$ & $\begin{array}{l}0.052^{\mathrm{a}} \\
0.060^{\mathrm{b}}\end{array}$ \\
\hline
\end{tabular}

a-fDifferent letters indicate significant differences between treatments $(\alpha=0.05)$. 
inversely proportional to the itinerary length, while specific energy was directly proportional to it (Table 6).

The energy balance was always positive and decreased in function of the travelled distance (Figure 5). The lowest observed value (68.39) was in the longest itinerary (F) during the late harvest season with high congestion (early morning), while the highest value (567.64) was obtained in the shortest itinerary (A) in early harvest season with low congestion (evening). In this itinerary a high vari- ability was observed (Figure 5 and Table 6).

Considering the road conditions in the different congestion (early morning and evening), the highest variation of the energy balance was recorded in itinerary A (40\%), while the lowest was obtained in itineraries $\mathrm{C}$ and $\mathrm{F}(2 \%)$. Considering the harvest season (late Summer and early Autumn), the highest variation was observed in itineraries D and E (2\%) and the lowest in the itinerary C (33\%).
$\mathbf{A}$

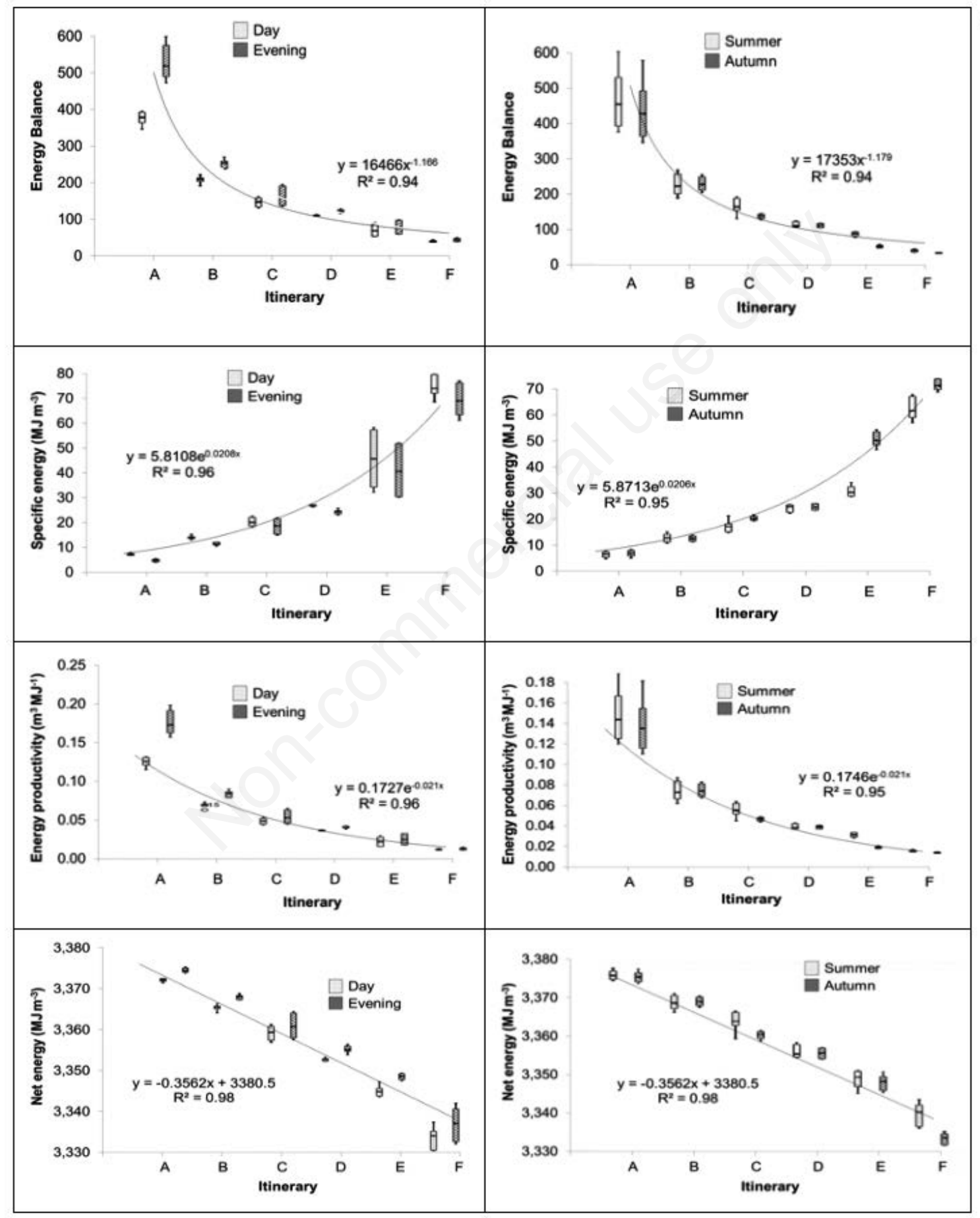

Figure 5. Energy balance, specific energy, energy productivity net energy box plots in function of the itinerary and congestion (A) and itinerary and season $(B)\left(P<0.0001\right.$ in all curves). $R^{2}=R$ squared statistic. 
Table 5. Descriptive analysis of the direct, indirect, maintenance and total energies.

\begin{tabular}{|c|c|c|c|c|c|c|c|c|c|c|}
\hline \multirow[t]{2}{*}{ Itinerary } & \multirow[t]{2}{*}{ Season } & \multirow[t]{2}{*}{ Congestion } & \multicolumn{2}{|c|}{$\begin{array}{l}\text { Direct energy } \\
\left(\mathrm{MJm}^{-3}\right)\end{array}$} & \multicolumn{2}{|c|}{$\begin{array}{l}\text { Indirect energy } \\
\left(\mathrm{MJm}^{-3}\right)\end{array}$} & \multicolumn{2}{|c|}{$\begin{array}{c}\text { Maintenance energy } \\
\left(\mathrm{MJm}^{-3}\right)\end{array}$} & \multicolumn{2}{|c|}{$\begin{array}{l}\text { Total energy } \\
\left(\mathrm{MJm}^{-3}\right)\end{array}$} \\
\hline & & & Mean & SD & Mean & SD & Mean & SD & Mean & SD \\
\hline A & $\begin{array}{l}\text { Summer } \\
\text { Autumn }\end{array}$ & $\begin{array}{l}\text { Day } \\
\text { Evening } \\
\text { Day } \\
\text { Evening }\end{array}$ & $\begin{array}{l}3.85 \\
2.80 \\
4.09 \\
2.97\end{array}$ & $\begin{array}{l}0.10 \\
0.22 \\
0.18 \\
0.29\end{array}$ & $\begin{array}{l}2.91 \\
2.06 \\
3.11 \\
2.20\end{array}$ & $\begin{array}{l}0.08 \\
0.17 \\
0.15 \\
0.23\end{array}$ & $\begin{array}{l}1.60 \\
1.13 \\
1.71 \\
1.21\end{array}$ & $\begin{array}{l}0.04 \\
0.10 \\
0.08 \\
0.13\end{array}$ & $\begin{array}{l}8.35 \\
5.99 \\
8.91 \\
6.39\end{array}$ & $\begin{array}{l}0.22 \\
0.49 \\
0.42 \\
0.64\end{array}$ \\
\hline B & $\begin{array}{l}\text { Summer } \\
\text { Autumn }\end{array}$ & $\begin{array}{l}\text { Day } \\
\text { Evening } \\
\text { Day } \\
\text { Evening }\end{array}$ & $\begin{array}{l}7.15 \\
5.73 \\
6.77 \\
5.89\end{array}$ & $\begin{array}{l}0.34 \\
0.35 \\
0.23 \\
0.23\end{array}$ & $\begin{array}{l}5.58 \\
4.43 \\
5.27 \\
4.55\end{array}$ & $\begin{array}{l}0.27 \\
0.28 \\
0.18 \\
0.19\end{array}$ & $\begin{array}{l}3.07 \\
2.43 \\
2.90 \\
2.51\end{array}$ & $\begin{array}{l}0.15 \\
0.15 \\
0.10 \\
0.10\end{array}$ & $\begin{array}{l}15.81 \\
12.59 \\
14.93 \\
12.95\end{array}$ & $\begin{array}{l}0.77 \\
0.78 \\
0.51 \\
0.52\end{array}$ \\
\hline $\mathrm{C}$ & $\begin{array}{l}\text { Summer } \\
\text { Autumn }\end{array}$ & $\begin{array}{l}\text { Day } \\
\text { Evening } \\
\text { Day } \\
\text { Evening }\end{array}$ & $\begin{array}{c}9.44 \\
7.75 \\
10.02 \\
10.17\end{array}$ & $\begin{array}{l}0.95 \\
0.49 \\
0.64 \\
0.37\end{array}$ & $\begin{array}{l}7.43 \\
6.06 \\
7.90 \\
8.02\end{array}$ & $\begin{array}{l}0.77 \\
0.40 \\
0.52 \\
0.30\end{array}$ & $\begin{array}{l}4.09 \\
3.33 \\
4.34 \\
4.41\end{array}$ & $\begin{array}{l}0.42 \\
0.22 \\
0.28 \\
0.17\end{array}$ & $\begin{array}{l}20.96 \\
17.14 \\
22.25 \\
22.61\end{array}$ & $\begin{array}{l}2.13 \\
1.11 \\
1.43 \\
0.83\end{array}$ \\
\hline D & $\begin{array}{l}\text { Summer } \\
\text { Autumn }\end{array}$ & $\begin{array}{l}\text { Day } \\
\text { Evening } \\
\text { Day } \\
\text { Evening }\end{array}$ & $\begin{array}{l}12.53 \\
11.43 \\
12.72 \\
11.61\end{array}$ & $\begin{array}{l}0.15 \\
0.61 \\
0.15 \\
0.10\end{array}$ & $\begin{array}{c}9.93 \\
9.04 \\
10.08 \\
9.19\end{array}$ & $\begin{array}{l}0.12 \\
0.50 \\
0.13 \\
0.08\end{array}$ & $\begin{array}{l}5.46 \\
4.97 \\
5.55 \\
5.05\end{array}$ & $\begin{array}{l}0.07 \\
0.27 \\
0.07 \\
0.04\end{array}$ & $\begin{array}{l}27.92 \\
25.44 \\
28.35 \\
25.86\end{array}$ & $\begin{array}{l}0.35 \\
1.39 \\
0.34 \\
0.22\end{array}$ \\
\hline E & $\begin{array}{l}\text { Summer } \\
\text { Autumn }\end{array}$ & $\begin{array}{l}\text { Day } \\
\text { Evening } \\
\text { Day } \\
\text { Evening }\end{array}$ & $\begin{array}{l}15.91 \\
14.33 \\
34.62 \\
31.27\end{array}$ & $\begin{array}{l}0.82 \\
0.30 \\
0.90 \\
0.75\end{array}$ & $\begin{array}{l}12.66 \\
11.39 \\
12.94 \\
11.66\end{array}$ & $\begin{array}{l}0.66 \\
0.24 \\
0.34 \\
0.28\end{array}$ & $\begin{array}{l}6.96 \\
6.26 \\
7.12 \\
6.42\end{array}$ & $\begin{array}{l}0.37 \\
0.13 \\
0.19 \\
0.16\end{array}$ & $\begin{array}{l}35.54 \\
31.98 \\
54.67 \\
49.35\end{array}$ & $\begin{array}{l}1.85 \\
0.66 \\
1.43 \\
1.19\end{array}$ \\
\hline $\mathrm{F}$ & $\begin{array}{l}\text { Summer } \\
\text { Autumn }\end{array}$ & $\begin{array}{l}\text { Day } \\
\text { Evening } \\
\text { Day } \\
\text { Evening }\end{array}$ & $\begin{array}{l}43.01 \\
38.06 \\
47.11 \\
45.75\end{array}$ & $\begin{array}{l}1.38 \\
0.86 \\
1.55 \\
0.94\end{array}$ & $\begin{array}{l}16.13 \\
14.25 \\
17.68 \\
17.16\end{array}$ & $\begin{array}{l}0.52 \\
0.32 \\
0.59 \\
0.36\end{array}$ & $\begin{array}{l}8.87 \\
7.83 \\
9.72 \\
9.44\end{array}$ & $\begin{array}{l}0.29 \\
0.18 \\
0.32 \\
0.20\end{array}$ & $\begin{array}{l}68.01 \\
60.14 \\
74.52 \\
72.35\end{array}$ & $\begin{array}{l}2.20 \\
1.36 \\
2.47 \\
1.48\end{array}$ \\
\hline
\end{tabular}

The values in the table are the mean of the three replications. SD, standard deviation.

Table 6. Average energy parameters per congestion, season, and itinerary.

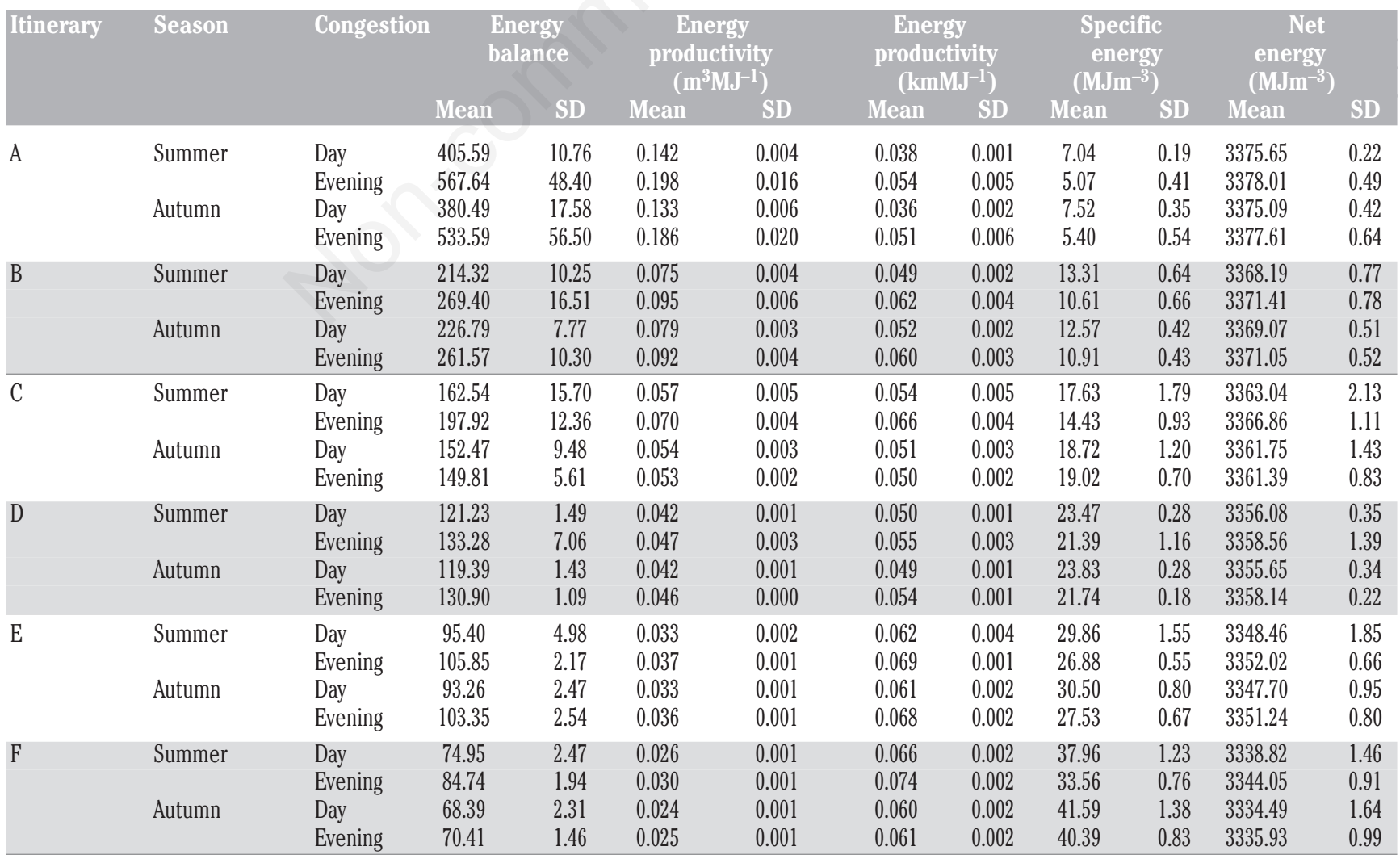

The values in the table are the mean of the three replications. SD, standard deviation. 
The highest value of specific energy was observed in the longest itinerary (F, $\left.41.59 \mathrm{MJ} \mathrm{m}^{-3}\right)$, whereas the lowest value was in the shortest $\left(\mathrm{A}, 5.07 \mathrm{MJm}^{-3}\right)$. The specific energy increased as an exponential function of the itinerary length (Figure 5). This energy parameter can also be affected by the weather and traffic conditions (Figure 5). In fact, travelling in different periods of the harvest season may occur a data variation lower than $17 \%$ (itinerary F), while performing the travel in different traffic conditions can lead to a variation until 28\% (itinerary A) (Table 6).

When the energy productivity is expressed per volume unit $\left(\mathrm{m}^{3}\right)$, the observed data followed the trend of a negative exponential function (Figure 5). In this case the values varied from 0.024 to 0.198 (Table 4).

The net energy data were very high, around $3357 \pm 21 \mathrm{MJm}^{-3}$ (Table 4). The net energy was inversely proportional to the itinerary length, with a linear trend (Figure 5). For the y-axis a short scale was used, otherwise the graphical representation was reduced to a horizontal line (Figure 5).

As expected, the statistical analysis revealed differences along the travelled itineraries, while similarities were recognized between early and late harvest season, with the exception of the energy productivity expressed per unit of distance. Considering the congestion, likeness were detected only for the net energy parameter (Table 4).

\section{Transportation costs}

Transport costs per unit of travelled distance $(\mathrm{km})$ and transported volume $\left(\mathrm{m}^{3}\right)$ are reported in table 4 . It is possible to appreciate that the variation interval is quite similar for both parameters, decreasing from 3.34 to 1.11 for the costs per kilometre and increasing from 0.86 to 3.97 for the costs per unit volume.
Statistical analysis highlighted likeness in the distance parameter and not in the transported volume (Table 4). The costs per unit of volume were similar in the harvest season (itineraries A, B, D and E) and different in the congestion level (Table 7).

The unit costs per travelled kilometre was a negative power of the distance (Figure 6), and linear increased for transported unit (Figure 6), with a high correlation coefficient $(>0.94$, p-values 0.072 and 0.089 respectively). The transportation costs are conditioned by the harvest season and traffic flow: for this reason, also indications about minimum and maximum transportation costs are given (Figures 4 and 5).

With a price of maize silage of $52.00 € \mathrm{t}^{-1}$, data analysis highlighted that the economic advantage exists if the maximum travel distance is lower than $18 \mathrm{~km}$, with a maximum transportation cost of $1.47 € \mathrm{~m}^{-3}$ (Figure 7).

\section{Discussion}

The productivity (expressed in dry matter transported per-hour) in this experimentation was similar to that calculated in other studies focused on woodchip transportation with agricultural convoys (Manzone and Balsari, 2015; Manzone and Calvo, 2017). Although the maize silage shows a density lower than to the woodchip (about 30\%), the amount of biomass transported was similar because in maize transportation is usually to use trailers equipped with specific containers sized to reach the maximum volume allowed by Italian traffic laws (up to $40 \mathrm{~m}^{3}$ ). The tests carried out showed that transportation times were influenced more by the congestion (early morning or evening) than by the road conditions (in late Summer or in early Autumn). For this reason, in supply chain

Table 7. ANOVA of the cost parameters per itinerary, season and congestion.

\begin{tabular}{|c|c|c|c|c|c|c|}
\hline \multirow[t]{2}{*}{ Itinerary } & \multirow[t]{2}{*}{ Season } & \multirow[t]{2}{*}{ Congestion } & \multicolumn{4}{|c|}{ Cost per unit } \\
\hline & & & Mean & SD & Mean & SD \\
\hline A & $\begin{array}{l}\text { Summer } \\
\text { Autumn }\end{array}$ & $\begin{array}{l}\text { Day } \\
\text { Evening } \\
\text { Day } \\
\text { Evening }\end{array}$ & $\begin{array}{l}3.21^{\mathrm{a}} \\
2.69^{\mathrm{b}} \\
3.34^{\mathrm{a}} \\
2.78^{\mathrm{b}}\end{array}$ & $\begin{array}{l}0.05 \\
0.11 \\
0.09 \\
0.15\end{array}$ & $\begin{array}{l}1.03^{\mathrm{a}} \\
0.86^{\mathrm{b}} \\
1.07^{\mathrm{a}} \\
0.89^{\mathrm{b}}\end{array}$ & $\begin{array}{l}0.02 \\
0.04 \\
0.03 \\
0.04\end{array}$ \\
\hline B & $\begin{array}{l}\text { Summer } \\
\text { Autumn }\end{array}$ & $\begin{array}{l}\text { Day } \\
\text { Evening } \\
\text { Day } \\
\text { Evening }\end{array}$ & $\begin{array}{l}2.01^{\mathrm{c}} \\
1.71^{\mathrm{d}} \\
1.93^{\mathrm{c}} \\
1.75^{\mathrm{d}}\end{array}$ & $\begin{array}{l}0.07 \\
0.07 \\
0.05 \\
0.05\end{array}$ & $\begin{array}{l}1.56^{\mathrm{c}} \\
1.33^{\mathrm{d}} \\
1.50^{\mathrm{c}} \\
1.36^{\mathrm{d}}\end{array}$ & $\begin{array}{l}0.06 \\
0.06 \\
0.04 \\
0.04\end{array}$ \\
\hline C & $\begin{array}{l}\text { Summer } \\
\text { Autumn }\end{array}$ & $\begin{array}{l}\text { Day } \\
\text { Evening } \\
\text { Day } \\
\text { Evening }\end{array}$ & $\begin{array}{l}1.72^{\mathrm{d}} \\
1.48^{\mathrm{e}} \\
1.80^{\mathrm{f}} \\
1.83^{\mathrm{f}}\end{array}$ & $\begin{array}{l}0.14 \\
0.07 \\
0.09 \\
0.05\end{array}$ & $\begin{array}{l}1.93^{\mathrm{e}} \\
1.66^{\mathrm{f}} \\
2.02^{\mathrm{g}} \\
2.05^{\mathrm{g}}\end{array}$ & $\begin{array}{l}0.16 \\
0.08 \\
0.10 \\
0.06\end{array}$ \\
\hline D & $\begin{array}{l}\text { Summer } \\
\text { Autumn }\end{array}$ & $\begin{array}{l}\text { Day } \\
\text { Evening } \\
\text { Day } \\
\text { Evening }\end{array}$ & $\begin{array}{l}1.75^{\mathrm{d}} \\
1.62^{\mathrm{d}} \\
1.77^{\mathrm{d}} \\
1.64^{\mathrm{d}}\end{array}$ & $\begin{array}{l}0.02 \\
0.07 \\
0.02 \\
0.01\end{array}$ & $\begin{array}{c}2.43^{\mathrm{h}} \\
2.25^{\mathrm{i}} \\
2.46^{\mathrm{h}} \\
2.28^{\mathrm{i}}\end{array}$ & $\begin{array}{l}0.03 \\
0.10 \\
0.03 \\
0.02\end{array}$ \\
\hline $\mathrm{E}$ & $\begin{array}{l}\text { Summer } \\
\text { Autumn }\end{array}$ & $\begin{array}{l}\text { Day } \\
\text { Evening } \\
\text { Day } \\
\text { Evening }\end{array}$ & $\begin{array}{l}1.34^{\mathrm{g}} \\
1.23^{\mathrm{h}} \\
1.36^{\mathrm{g}} \\
1.25^{\mathrm{h}}\end{array}$ & $\begin{array}{l}0.06 \\
0.02 \\
0.03 \\
0.03\end{array}$ & $\begin{array}{l}2.97^{\mathrm{m}} \\
2.72^{\mathrm{n}} \\
3.03^{\mathrm{m}} \\
2.78^{\mathrm{n}}\end{array}$ & $\begin{array}{l}0.13 \\
0.04 \\
0.07 \\
0.06\end{array}$ \\
\hline $\mathrm{F}$ & $\begin{array}{l}\text { Summer } \\
\text { Autumn }\end{array}$ & $\begin{array}{l}\text { Day } \\
\text { Evening } \\
\text { Day } \\
\text { Evening }\end{array}$ & $\begin{array}{l}1.24^{\mathrm{h}} \\
1.11^{\mathrm{m}} \\
1.35^{\mathrm{g}} \\
1.31^{\mathrm{g}}\end{array}$ & $\begin{array}{l}0.03 \\
0.02 \\
0.04 \\
0.03\end{array}$ & $\begin{array}{l}3.66^{\mathrm{p}} \\
3.29^{\mathrm{q}} \\
3.97^{\mathrm{r}} \\
3.87^{\mathrm{r}}\end{array}$ & $\begin{array}{l}0.11 \\
0.06 \\
0.12 \\
0.07\end{array}$ \\
\hline
\end{tabular}

The values in the table are the mean of the three replications. SD, standard deviation. ${ }^{\text {a-r }}$ Different letters indicate significant differences between treatments ( $\left.\alpha=0.05\right)$. 
management of biogas plants needs to give higher attention to the potential traffic jams linked to rush hours and road characteristics (urban or extraurban roads, one-lane or multi-lane roads) of the itineraries choose to perform the biomass transportation than the eventual worst weather conditions (rain, fog) present during the transport. Nevertheless, the average forward speed $\left(27.40 \mathrm{~km} \mathrm{~h}^{-1}\right)$ can suffer of a significant reduction (about 15\%) in presence of fog (in early Autumn) and storms (in late Summer) that may cause slowdowns due to poor visibility. Traffic congestion and harvest period (in early Autumn or in late Summer) affected also the productivity (approximately 25\%) highlighting the lower values in early Autumn $\left(24.41 \mathrm{~m}^{3} \mathrm{~h}^{-1}\right)$. In this regard, we wish to recall that the loading times can have a great influence on the total working time, especially in short itineraries where their incidence is higher. In addition, the loading times are unquantifiable, especially during the work planning, because they depend from the logistic aspects of the harvesting operation (waiting times linked to trailers turn over) and regular layout of the field (higher is the irregular layout, higher are the manoeuvres) as observed by Orfanou et al. (2013).

Independently by the transport distance and route conditions, the transportation of the maize silage using agricultural convoys was always positive from the energetic point of view, with an energy balance higher than 43 . This is a good value, because it is in line with the values obtained for forestry residues (Murphy et al., 2014) and woodchip (Manzone and Calvo, 2017) transportation. Energy balance showed a higher variability in the shortest itinerary, mainly caused by an increased incidence effect of unpredictable road constraints on total travel time, as observed also by other authors in woodchip transportation (Manzone and Calvo, 2017). On the contrary, the bad weather conditions (fog, drizzle, rain) affected mainly longer itineraries. Fuel and lubricant (direct energy) had an incidence near $45 \%$ on total energy requirement while the incidence of tractor and trailers embodied energy (indirect energy) was only near 35\%; also in this case, the results are in line with those found by other authors for biofuel (Murphy et al., 2014) and woodchip transportation (Manzone and Calvo, 2017). The direct energy resulted inversely proportional to the itineraries length because the incidence of the indirect energy decrease as a function of the vehicles time used (Bijrjesson, 1996). Repair and maintenance highlighted the lowest contribution (average 20\%) on the total energy requirement. This aspect is well known in the biomass sector, where similar results are obtained by other machines: planters (Manzone, 2016) and chippers (Manzone, 2015), and loaders (Manzone, 2018). Another key point to support the energetic sustainability of the maize silage transportation using agricultural convoys is the high positive value of the net energy per unit of transported volume: in fact, the input energy required was always lower than $1.5 \%$, compared to the transported material energy content. Considering the economic aspect, the maximum distance to get a profit is only $18 \mathrm{~km}$, as transportation costs are affected by the distance, with an average increase of $0.06 €$ per travelled kilometre. The maize silage transportation is connected to the harvesting operations: for longer distances (over $15 \mathrm{~km}$ ), it is difficult to plan a trailer turnover logistic, to allow the continuous operation of the harvester (Velazquez-Marti and Fernadez-Gonzales, 2010). Travelling with good road conditions was advantageous, as found in another study on woodchip transportation (Manzone and Calvo, 2017). The development of a transportation model could also be useful for the biomass transportation, as already done in other contexts (Harmon and Luck, 2016). For longer distances, it could be convenient to use trucks, not only for their higher payload and forward speed (Manzone and Balsari, 2015; Manzone and Calvo, 2017), but also for their lower environmental impact, especially in roundtrips higher than $25 \mathrm{~km}$ (Bacenetti et al., 2015). In this case, it is necessary to transfer the maize silage form the shuttle trailer (used in field) to the truck roadside. If the transportation is instead performed in the farm yard using conventional loaders (requiring the ground discharge of the material), significant biomass losses may occur (Manzone, 2017).

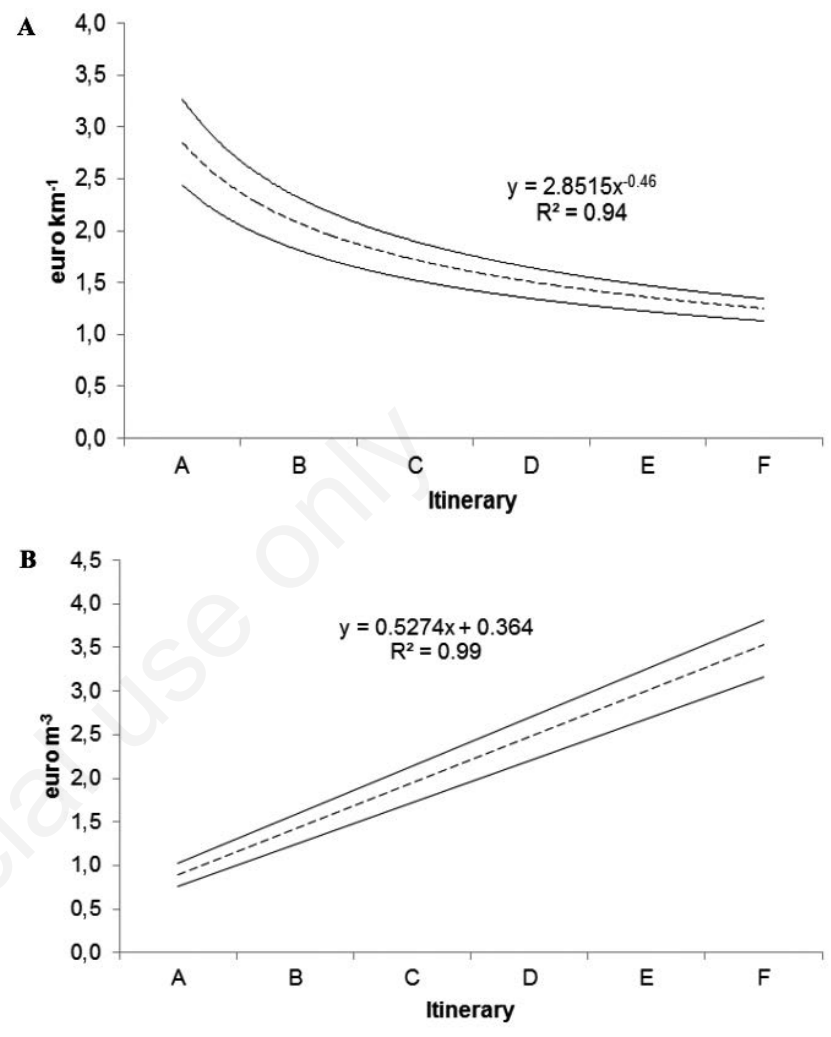

Figure 6. Cost per travelled kilometre and per cubic meter of biomass transported in function of the itinerary (average: dot line; maximum and minimum: continuous lines) $(\mathbf{P}<\mathbf{0 . 0 0 0 1}) . R^{2}=R$ squared statistic.

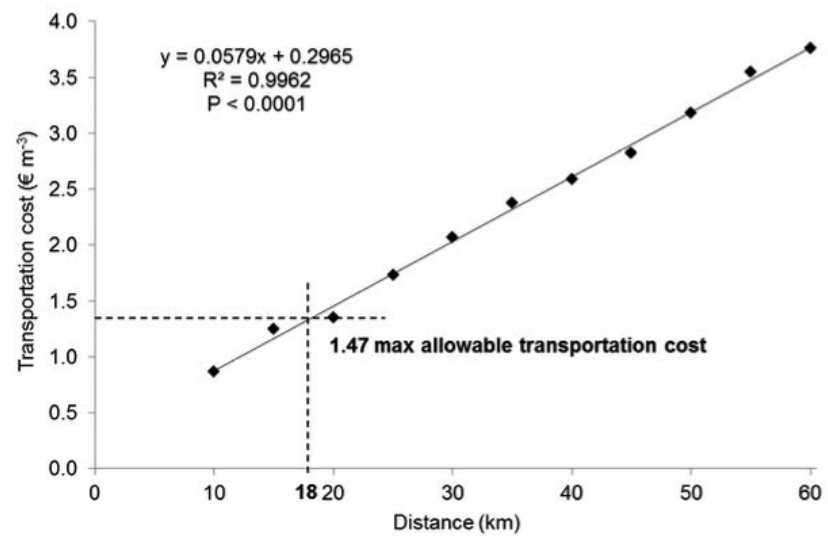

Figure 7. Economic sustainability of biomass transportation in function of the travelled distance. $R^{2}=R$ squared statistic. 


\section{Conclusions}

The study showed that the maize silage transportation using agricultural tractors depends not only on the travelled distance, but also on the road congestion and the weather conditions. Travelling with low congestion is less energetic and economic expensive than transporting the biomass during the high congestion.

The performed tests highlighted that the energy evaluation is always positive also for distances until $60 \mathrm{~km}$; on the contrary, the current market value of maize silage $\left(52.00 € \mathrm{t}^{-1}\right)$ limits the transportation distance to $18 \mathrm{~km}$.

The farmers may use the described methodology to evaluate slowdowns due to the road and the weather conditions also for the harvesting of the biomass. For example, if he plans the transportation in the evening instead of in the morning, he may know how much the travel times will differ and correctly plan the harvesting.

The tests performed in this experimentation were time consuming and quite expensive, because many itineraries were investigated also in unfavourable weather conditions: for these reasons, the possibility to use a model to foresee the transportation times could be useful.

\section{Highlights}

- Agricultural vehicles were considered in used on maize for silage transportation;

- Six itineraries, two climate weather conditions, and two congestions level were considered;

- The energy balance is always positive;

- The energy spent depend by the distance and the climate weather conditions;

- The maize silage transportation is economically sustainable up to $18 \mathrm{~km}$.

\section{References}

ASAE (American Society of Agricultural Engineers). 1999. ASAE Standards: Agricultural Machinery Management; EP466.2.

Bacenetti J, Negri M, Lavarelli D, Ruiz Garcia L, Fiala M. 2015. Economic performances of anaerobi digestion plants: effect of maize silage energy density at increasing transport distances. Biomass Bioenerg. 80:73-84.

Bacenetti J, Sala C, Fusi A, Fiala M. 2016. Agricultural anaerobic digestion plants: What LCA studies pointed out and what can be done to make them more environmentally sustainable? Appl. Energy 79:669-86.

Bijrjesson P. 1996. Energy analysis of biomass production and transportation. Biomass Bioenerg. 11:305-18.

Dinuccio E, Balsari P, Gioelli F, Menardo S. 2010. Evaluation of the biogas productivity potential of some Italian agro-industrial biomasses. Bioresour. Technol. 101:3780-3.

Fluck RC. 1985. Energy sequestered in repairs and maintenance of agricultural machinery. Trans. ASAE 28:1270-9.

Harmon J, Luck B. 2016. Data recording methods and time-motion analysis of the forage harvest process. American Society of Agricultural and Biological Engineers Annual International Meeting, ASABE 2016, paper number 162462281.

Höhn J, Lehtonen E, Rasi S, Rintala J. 2014. A Geographical Information System (GIS) based methodology for determination of potential biomasses and sites for biogas plants in southern Finland. Appl. Energy 113:1-10.

Jenkins TL, Sutherland JW. 2014. A cost model for forest-based biofuel production and its application to optimal facility size determination. For Policy Econ. 38:32-9.

Magagnotti N, Spinelli R. 2012. COST Action FP0902 - Good practice guideline for biomass production studies, CNR IVALSA. Florence, Italy. 41p. Available from: www. forestenergy. org

Manzone M. 2015. Energy consumption and CO2 analysis of different types of chippers used in wood biomass plantations. Appl. Energy 156:686-92.

Manzone M. 2016. Energy and CO2 emissions associated with mechanical planters used in biomass plantations. Biomass Bioenerg. 87:156-61.

Manzone M. 2017. Loader performance during woodchip loading. Biomass Bioenerg. 98:80-84.

Manzone M. 2018. CO2 emissions and energy consumption of loaders in woodchip loading operation. Biomass Bioener, 109:10-15.

Manzone M, Balsari P. 2015. The energy consumption and economic costs of different vehicles used in transporting woodchips. Fuel 139:511-5.

Manzone M, Calvo A. 2017. Woodchip transportation: Climatic and congestion influence on productivity, energy and $\mathrm{CO} 2$ emission of agricultural and industrial convoys. Renew. Energy 108:250-9.

Manzone M, Spinelli R. 2014. Efficiency of small-scale firewood processing operations in Southern Europe. Fuel Process. Technol. 122:58-63.

Menardo S, Balsari P, Tabacco E, Borreani G. 2015. Effect of Conservation Time and the Addition of Lactic Acid Bacteria on the Biogas and Methane Production of Corn Stalk Silage. Bioener. Res. 8:1810-23.

Murat YS, Kutluhan S, Cakici Z. 2014. Investigation of Cyclic Vehicle Queue and Delay Relationship for Isolated Signalized Intersections. EWGT2013-16th Meeting of the EURO Working Group on Transportation. Procedia Soc. Behav. Sci. 111:252-61.

Murphy F, Devlin G, McDonnell K. 2014. Forest biomass supply chains in Ireland: A life cycle assessment of GHG emissions and primary energy balances. Appl. Energy 116:1-8.

Negri M, Bacenetti J, Brambilla M, Manfredini A, Cantore C, Bocchi S. 2014. Biomethane production from different crop systems of cereals in Northern Italy. Biomass Bioener. 63:321-9.

Orfanou A, Busato P, Bochtis D, Edwards G, Pavlou D, Sørensen CG, Berruto R. 2013. Scheduling for machinery fleets in biomass multiple-field operations. Comput. Electron. Agricult. 94:12-9.

Pordesimo LO, Hames BR, Sokhansanjc S, Edens WC. 2005. Variation in corn stover composition and energy content with crop maturity. Biomass Bioenerg. 28:366-74.

Sopegno A, Calvo A, Berruto R, Busato P, Bochtis D. 2016. A web mobile application for agricultural machinery cost analysis. Comput. Electron. Agricult. 130:158-68.

UNI EN 14774-2. Solid biofuels, determination of moisture content - oven dry method, Part 2: total moisture - simplified method; 2010.

UNI EN 14918. Solid biofuels, determination of calorific value; 2010.

Velazquez-Marti B, Fernandez-Gonzalez E. 2010. Mathematical algorithms to locate factories to transform biomass in bioenergy focused on logistic network construction. Renew. Energ. $35: 2136-42$. 